\title{
Playing with Practice Theory: Preliminary Remarks on the Work of Performance Ecologies in $\mathbf{2 1}^{\text {st }}$ Century Bangkok
}

\author{
Lowell Skar (โลเวล สการ์) \\ BALAC Program, Faculty of Arts, Chulalongkorn University, Bangkok, \\ Thailand \\ Lowell.S@chula.ac.th
}

\begin{abstract}
This article builds a framework for considering the place of contemporary performance groups in $21^{\text {st }}$ century Bangkok. It grounds performance groups in ensembles of performance practices developed by groups as part of their unique performance cultures. The varied ensembles of performance practice of three such groups - the Pichet Klunchun Dance Company, the 8X8 Theatre Group, and the B-Floor Artist Collective are embodied in these groups' distinctive interactive performance styles and tied to the different creative spaces where they work. The groups' artistic practices and their working spaces are produced within larger ecologies of performance spanning the urban landscape of $21^{\text {st }}$ century Bangkok. The article suggests this framework as a richer way to study performance cultures in Thailand. Relating the performance landscape of Bangkok's contemporary theatre scene to the embodied artistic practices of different groups shows how their unique performance cultures help to enliven the city's distinctive cultural ecology of performance.
\end{abstract}

\section{Keywords}

practice theory - performance studies - Bangkok theatre - cultural ecologies - artistic research 
บทคัดย่อ

ทฤษฎีการปฏิบัติ ข้อสังเกตเบื้องต้นเกี่ยวกับงานด้านนิเวศวิทยาการแสดงที่กรุงเทพฯ ใน ศตวรรษที่ 21

บทความนี้สร้างกรอบการพิจารณาสถานภาพของกลุ่มการแสดงร่วมสมัยในกรุงเทพฯ, แห่ง ศตวรรษที่ 21 โดยใช้การปฏิบัติของกลุ่มการแสดงที่มีวัฒนธรรมการแสดงเฉพาะที่แตกต่างกัน 3 กลุ่มคือ คณะร่ายรำพิเชษฐ กลั่นชื่น คณะละคร $8 \times 8$ และคณะศิลปินบีฟลอร์ แต่ละคณะมีวิถี หรือสไตล์การแสดงแบบมีปฏิสัมพันธ์กับผู้ชมในรูปแบบที่แตกต่างกัน และมีพื้นที่ในการทำงาน สร้างสรรค์ที่ไม่เหมือนกัน การปฏิบัติอันมีลักษณะศิลปะของกลุ่ม รวมทั้งพื้นที่ในการทำงาน สร้างสรรค์ของกลุ่มทั้งสามนี้ อยู่ในนิเวศวิทยาการแสดงที่ครอบคลุมภูมิทัศน์เมืองในศตวรรษที่ 21 ของกรุงเทพฯ

บทความนี้ชี้ให้เห็นว่า กรอบการพิจารณาการปฏิบัติเพื่อการแสดงและพื้นที่ที่ใช้ในการฝึก ซ้อมปฏิบัติ เป็นวิธีการศึกษาที่ให้ผลดีกว่า เพื่อเรียนรู้วัฒนธรรมการแสดงของประเทศไทย พื้นที่ การแสดงละครร่วมสมัยกับการปฏิบัติการทางศิลปะของคณะนักแสดงกลุ่มต่างๆ ที่แตกต่างกัน นี้ เป็นวัฒนธรรมการแสดงที่เป็นอัตลักษณ์ โดดเด่นไม่เหมือนใคร ทำให้นิเวศวิทยาการแสดงของ กรุงเทพฯ มีชีวิตชีวา

\section{1 \\ Introduction: Bangkok's Contemporary Performance Ecologies}

Performance is a vital part of life in Bangkok. The diversity and ubiquity of performances across its urban spaces are not limited to its many stages, galleries, or theatres. Performance reaches onto its streets and alleys, as well as into its many schools and malls and, increasingly, across online platforms like Facebook, YouTube and TikTok. How to make sense of the great variety of performances in Bangkok today? Performance in the City of Angels forms a diverse and complex cultural landscape of loosely interconnected urban ecological niches that embody distinct performance cultures. These performance cultures are constituted by divergent artistic and social practices, which are in turn entangled in messy, but meaningful, mixes of skills and talents embodied by individuals and groups of people. Taken together, they offer diverse forms of exposure, vulnerability, experiment, and resilience, and open to more modes of involvement, interpretation, dialogue, and engagement.

The contemporary performing arts landscape in Bangkok forms a lively and fragile field of cultural ecosystems centered on performance groups which embody distinctive sets of cultural practices. Practices may be understood as embodied, embedded, and meaningful "bundles of 'doings and sayings"” which the performing arts groups use to assemble and stage their work and which involve both "practical activity and representations" (Warde 2005, 134). 
Performances can be viewed as specific situated and sharable assemblages of embodied practices, symbolic or expressive types of doing things or activities which are also things that are done (Diamond 1996, 1). These performances are grounded in interconnected projects and processes situated in specific cultural situations which may be interpreted as performance ecologies or viable intra-active and vulnerable performance cultures forming interwoven matrices composed of the mutually affecting elements that contribute to Bangkok's field of performances.

In the past quarter-century, two major changes have reworked the cultural environment shaping Bangkok's live performance ecologies: the first was the turmoil caused by the Asian Financial Crisis that began in Bangkok in July 1997, and the second is the current COVID 19 pandemic, which noticeably began affecting Bangkok from the March 2020 lockdowns throughout Thailand and around the world. The Asian Financial Crisis reworked Bangkok's performance ecologies throughout the early $21^{\text {st }}$ century, and the COVID pandemic has already begun to radically transform what performance is and can do in more fundamental ways. Even now, as Bangkok is starting to reopen after the first pandemic lockdown, it is still not clear how its performance ecologies will respond or operate in this new cultural environment shaped by the ongoing pandemic.

The article seeks to link three performance groups based in Bangkok to distinctive forms of artistic practice they developed in the $21^{\text {st }}$ century using practice theory. The three noteworthy performing arts groups form distinct performance cultures at work in and beyond Bangkok. Each of them emerged in the aftermath of the 1997 Asian Financial Crisis and each is still working during the COVID 19 pandemic. These groups have been key parts of Bangkok's $21^{\text {st }}$ century performance landscape: the Pichet Klunchun Dance Company, the $8 \times 8$ Theatre Group, and B-Floor Artist Collective. Given their resilient histories, diverse experiences and working processes, they may also provide clues on how performance cultures informing today's distinct cultural ecologies may work in the current era of the global COVID 19 pandemic.

This section will introduce the three above $21^{\text {st }}$-century groups as three distinct ecological niches in Bangkok's performance landscape. One site that links the three groups considered here is the Bangkok Fringe Festival, which began in 1999 at the Patravadi Theatre, after the Asian Financial Crisis. This festival provided a venue and a focal point for emerging theatre and performing arts 
groups in Thailand at the time. The Patravadi Theatre was a small open-air theatre established a few steps from the Chao Phraya River in Thonburi 1992 by Patravadi Mejudhon (Khru Lek) as an independent performing arts space for experimenting with traditional and modern styles of performance in Bangkok. ${ }^{1}$ The Theatre came to include a café, Studio 9, by the river, where diners could enjoy performances by young artists, a residential space, a gallery, a library, a semi-outdoor stage Studio 1, used for staging productions, rehearsal studios, where inexpensive dance classes took place on weekends, and apartments for Patravadi Theatre's artists and guest artists. This creative space formed a veritable cultural ecosystem for the emerging performing arts community in the heart of Bangkok. The festival ran in the cooler months of January and February for several years, and served as a key ecological niche, helping to generate the Thai theatre scene in the post-Asian Financial Crisis Bangkok. ${ }^{2}$ Since 2002, the Bangkok Theatre Festival, first held by the Chao Phraya River in the Banglumpu area of Bangkok, became the annual hothouse for the theatergoing culture, starting first from a tiny group and slowly grew since then. This festival is run by a key supporting organization, the Bangkok Theatre Network and since the floods of 2011, has moved to other Bangkok venues, including a major center at the BACC in Bangkok's central shopping district.

Pichet Klunchun, Nikorn Saetang, and the two remaining founding members of B-Floor-Jarunun Phantachat (Jaa) and Teerawat Mulvilai (Ka-ge)-all began their work in performance after the Asian Financial Crisis. All benefitted from staging their work at the Patravadi Theatre for its Bangkok Fringe Festival since 1999, and its successor, the annual Bangkok Theatre Festival in 2002. Their ongoing work helped each group develop a unique bundle of artistic practices which they used to establish their distinctive performance styles with that helped define the cultural ecosystems that sustained them and helped to shape Bangkok's $21^{\text {st }}$ century performance landscape. In recognition of their work in performance, they have all received the Silpathorn Award for Performing Arts from the Thai Office of Contemporary Art and Culture.

The Pichet Klunchun Dance Company, founded by Pichet Klunchun, Thailand's most renowned dancer and choreographer, is best known for its unique blend of Thai dance traditions and contemporary dance. Pichet's signature style is grounded in classical Thai masked dance or khon, which he learned

1 This noted actress, stage director, and novelist became a National Artist in 2014. She currently is based in Hua Hin, a noted beach town south of Bangkok, where she runs the Patravadi High School to teach the performing arts, including elementary classes and art camps, shows at the Vic Hua Hin Theatre and Gallery.

2 It was forced to close in 2011 due to the big floods in Bangkok, when the damage to the space was too great to return it to a functioning theatre. 
from Chaiyot Khummanee, one of Thailand's best khon masters in the giant role. While developing a repertoire of dance pieces rooted in his experience of learning to dance from his teacher, combining his unique body movement in environments formed by simple strong visual images and changing Thai and global music since 1998, he has gone on to receive global attention for other work, too. From his work I Am a Demon, he went one to create his most performed piece, Pichet Klunchun and Myself, began in 2004 with Jérôme Bel from France, and founded his LifeWork Company to produce new work, performed in Asia, Europe and the USA. Having founded a professional dance company in the 2010s, in 2017 he set up Chang Theatre in Thonburi, where his company rehearses and performs, along with other visiting artists. His work aims to reimagine classical Thai dance for the world of contemporary dance. Seeking to expand beyond conventional performance space requirements the company also reduces the boundary between performers and audience.

Nikorn Saetang is a founder and director of the $8 \times 8$ Theatre Group, which began in the $8 X 8$ Theatre (named for its small $8 \mathrm{~m} \times 8 \mathrm{~m}$ size) in 1998 as a pioneering independent theatre space in Thailand begun in 1998, run in a townhouse (now demolished) in the Sam Yarn area of Bangkok, with seats for about 30 people. These efforts inspired several theatre friends to start their own spaces. He studied at the international school of Theatre of Jacques Lecoq in France in 1999-2000. After being awarded a fellowship to work in Japan for three months in 2000, he has often been involved with Japanese groups. In 2007 he wrote and directed a play about the Yasukuni Shrine, working with Japanese actors in Thailand on the project. In 2013 he received a grant from the Asian Cultural Council for a 6-month artist residency in New York City. Over time, he learned from real work experience, training with professionals and working on every part of the production. His practical viewpoint helps him to look for how to solve problems. His productions often address social issues and ethical dilemmas, such as his notable works Insomnia, Desperation of God and Phob Ruk. With more than 25 plays to his name, Nikorn is regarded as one of the most influential figures in Thai performance.

B-Floor is a "collective of artists with various backgrounds" which combines elements of physical theatre, multimedia visual and soundscapes, props and objects, and innovative staging in their work, operating by a principle of acting more and talking less. They work as a group of artists in various spaces for workshops and performances, developing their projects over long periods of time, with each project given its own focus depending how which members of the collective are involved or leading it. Two co-founders of this collective are Jarunun Phantachat (Jaa) and Teerawat Mulvilai (Ka-ge), who first worked with eight others since 1999, often meeting daily at the Pridi Banomyong 
Institute on Thonglor Road, where they tried out doing things they had never seen or done. Although the collective's membership has changed over time, its members take on various roles as needed for each project - performer, producer, director, dramaturg, artistic director, fundraiser, company manager, contact and coordinator. Jarunun often manages the space and looks for venues and developing the company's annual policy. In 2005-2006, new members joined us, and some founding members left in 2008 and others came. This led to the group wondering in 2008 who composed B-Floor and formed it as a new group, which continues to this day with some new members. Still consisting of ten members, of the original founding members, only two remain - Teerawat and Jarunun.

The next part of this paper will suggest a framework for situating contemporary performance groups in Bangkok. This framework will then be used to sketch out how the above three performance groups relate to the distinctive bundles of performance practices that each has created and used to create its own identity. Their unique performance-making practices evolved within distinctive cultural ecologies that emerged after the 1997 Asian Financial Crisis. Each of these groups focuses on experimental forms of embodied action developed for live mostly young university-educated audiences, often embedding their activities in settings composed of hybrid assemblages of images, scenes and sounds from local and global sources, and whose collaborative projects often receive international support and work across national boundaries. Each group also shaped its activities by the need it had to find spaces for rehearsing and performing, and to find funding to develop and show their performances. Their performance projects form part of the living performance landscape of Bangkok as ecological niches of performance forming its current cultural life.

\section{The Face as an Entry Point for Appreciating Practices of} Performance

Performance is "always a doing and a thing done" (Diamond 1996, 1), which involves a kind of face-to-face encounter in a contact zone. Serge Daney suggested in 1992 that "every [artistic] 'form' is a face looking at us." (Daney 2004). ${ }^{3}$

3 Diamond (1996, 1), elaborates on these two aspects, saying performance includes both "embodied acts, in specific sites, witnessed by others (and/or the watching self)" and "the thing done, the completed event framed in time and space and remembered, misremembered, interpreted and passionately revisited across a pre-existing discursive field." This dual understanding of performance as process and event is still key in recent research, for example in Diana Taylor's Performance (2016). 
By interpreting living and moving works of art as faces - subjects looking at us - with an agency and ability to affect us with their expression, we are exposed to something both vulnerable and demanding something of us. Such a view of the live work of art stresses its ability to catch us up in its gaze and to engage us. The demand such works makes to engage us is most obvious in performances, since performance establishes reciprocal relations between the living work of the performer and the viewer. ${ }^{4}$ Engaging a performance is always a type of interaction, an encounter in a contact zone where, as Marina Abromović has said, "the artist is present" to the viewer, including during her appearance in Bangkok in late 2018 as part of the city's first Biennale. ${ }^{5}$

Seeing the work of art as a face refocuses attention from the nature of the work as a thing to the living interactions with the work in its production. It suggests that understanding performance is less about what any performance is than what it does for us and what we can do for it. It also suggests that performance is more about focusing on establishing relationships and alliances than on determining the work's identity. Seeing the work of performance as chiefly about practices of interactive "alliance-making" or making connections takes us toward understanding performance as part of an ecosystem of embodied meaning. Seeing the work of art, such as a performance, as a face, thus provides an entry point to seeing performances as parts of living cultural ecologies.

With this entry point of faces as singular, vulnerable, often inscrutable and rarely isolated more-than-factual instances of embodied life demanding a response, the paper will move on to consider the embodied engagements with a living face in performances. These engagements also involve assemblages of learned practices, as meaningful bundles of doing and saying, embedded in complex ensembles. These assemblages of practice crystallize into performanc$e s$, which are situated and sharable bundles of practices that are grounded in interconnected projects and processes forming living cultural ecologies. These ecologies are intra-active viable, vulnerable performance cultures - matrices interwoven and mutually affecting elements.

4 See the discussion linking the face to performance in Cody and Cheng $(2015,3-4)$.

5 See various recordings of her performances in the 2010 retrospective of her work at the Museum of Modern Art in New York <https://www.moma.org/calendar/exhibitions/964>. For more details, see the trailer for her 2012 documentary https://youtu.be/YcmcEZxdlv4 and her December 2015 TED Talk "An Art Made of Trust, Vulnerability and Connection | Marina Abramović" https://youtu.be/M4so_Z9a_uo. She also did this work in the BACC during the Bangkok Biennale 2018/2019. 
A major new way to understand social phenomena and cultural life that has developed since the 1970s has focused on "practices." Its power and influence is sometimes credited with producing a so-called "practice turn" in the human sciences. (Schatzki, et al. 2001) ${ }^{6}$ Practice theories encompass a broad set of approaches that seek to analyze the relationships between established structures of culture and the ways people behave in those structures, often through focusing on specific performance episodes, which depend on situational flexibility, variability, and creativity in human action.

Practice has become a key concept in diverse disciplines like philosophy, history, sociology, anthropology, and technology studies, and is also central to artistic research and performance studies. Given this diversity, it is perhaps not surprising that there are diverse approaches to studying practice. Broadly speaking, however, practices are ways of enacting patterned sets of elements, especially materials, skills, and meanings, which constitute the lives of those who enact them. Despite being patterned and composite activities, practice is never fixed or merely routine. Practice always requires "play" to work. Combining things, embodied in rehearsed actions, in significant repertoires of activity requires creativity. The publicly organized and recognizable bundles of doing things with words and actions are always open to adjustment and improvisation in unique situations. These embodied, embedded and significant bundles of doing and saying are the means through which society and culture emerges, something especially clear in local circumstances.

Decades of focusing on practices has produced many theories of practice more than one practice theory, but since most theories focus on the body in action, John Postill $(2010,11)$ stresses that collectively they form "a body of work about the work of the body." As mainly theories of bodies in action, especially the action of everyday life, practice theories stress how several types of knowledge are produced in and through bodily involvement in learned, shared, situated and collective practices. The stress on practices as embodied action more than acts of the mind places knowledge in the interactions between people and in arrangements in the world. As such, “[p]ractice theories' central claim is to move beyond problematic dualisms like structure and agency, methodological individualism and holism, determinism and voluntarism, and

6 Theodore Schatzki and his co-authors in their seminal book on the "practice turn" define practice a "set of actions" and as a "nexus of doings and sayings" which includes what people say and write with what they do (Schatzki 20o1b, 48, 53). They also say practices are "embodied, materially mediated arrays of human activity centrally organised around shared practical understanding" (Schatzki 2001a, 2). 
subject and object." (Welch and Warde 2015) These theories have allowed anthropologists, sociologists and others who analyze cultural life to consider both shaping structures and individual or group agency in interpreting human action.

Andreas Reckwitz (2002) refined "practice" for more empirical research, viewing it as a distinctive "configuration... of several elements, interconnected to one another: forms of bodily activities, forms of mental activities, 'things' and their use, a background knowledge in the forms of understanding, know-how, states of emotion and motivational knowledge" (Reckwitz 2002, 249). This "configuration" or complex of "body/knowledge/things" is understandable both for those involved in the practice and to outside observers as "a routinized way in which bodies are moved, objects are handled, subjects are treated, things are described and the world is understood" (Reckwitz 2002, 249-50). Elizabeth Shove and her collaborators (Shove et al. 2012; Hui et al. 2017) build on this view, seeing practices as emerging from interactions and linkages in three key dimensions of activity: materials, including things, technologies, tangible physical entities and spaces; competences, covering the skills and know-how implied in practice; and meanings, such as symbolic meanings and ideas (Shove, et al. 2012, 14). As the current mainstream view on practice theory, the above view stress practices as "an amalgam of elements,' as 'complexes' or 'bundles' of meanings, competences, and material objects" (Shove, et al. 2012, 40, 81) which appear as "integrative performances... reproduced as provisionally recognizable entities." (Shove, et al. 2012, 82). This approach to practice permits studying social and cultural reality by considering how materials, competences and meanings arise as stable and socially shared configurations of activities in various cultural arenas.

In short, current mainstream views (Shove, et al. 2012) stress practice as action that is:

1. embedded in an environment composed of assemblage of living and non-living, human and non-human things, i.e., part of an ecosystem;

2. embodied centered on the living skillful body or bodies "[seen as] the nexus of 'arrays of activities' (i.e. practices) that agents perform with greater or lesser commitment, dexterity and grace;"

3. (re)producible forms of meaning and knowledge, that is, human activities including shared skills and common understanding which are made by doing.

Similarly, Alan Warde provides a succinct minimal view of practices as "an organized, and recognizable, socially shared bundle of activities that involves the integration of a complex array of components: material, embodied, ideational and affective. Practices are sets of 'doings and sayings'; they involve both 'practical activity and its representations'" organized sets or bundles of "doings and 
sayings'; they involve both 'practical activity and representations'" (Warde $2005,134) .{ }^{7}$ Practices provide an ideal pattern which individuals consciously or unconsciously replicate each performance they acquire by repeatedly doing it. This practice approach is useful to think about cultural and social processes beyond dichotomies or binaries, recognizing how both agency and structure shape these processes. For practice to work, it requires "play." Welch and Warde (2015) argue that general understandings pervade practice complexes, and then develop this idea as an example of how culture is a phenomenon constituted by practices.

Davide Nicolini elaborates on the above mainstream view, seeing practices as "regimes of a mediated object-oriented performance of organised set of sayings and doings.... [which are called] 'practices' when they have a history, social constituency and hence, a perceivable normative dimension." (Nicolini 2017, 21)..$^{8}$ Collectively, "practice" approaches focus on the idea that people are both influenced by their environments or social structures and able to influence their environments or social structures. The circular relationship between people and environment or society is thus central to practice theories.

Since this view of human activity locates knowledge among groups and situations more than in individuals, it grounds knowledge in an ecosystem. This insight is key for artistic research and especially for research in the performing arts, where the role of performance - enacted and embodied practice within a situation - stresses how knowledge and insights emerge from the interaction of performers and audience in a performance space.

Identifying Artistic Performance Practices through their Play

Practice approaches do not just deal with mundane activities. They can also help to mark out or frame specific types of activity as "special" processes and

7 Linking practice to social groups and interpretive communities, Lewis $(2013,20)$ defines practice as "intersubjective, public, and widely available patterns of repeatable action around which groups can organize activities."

8 He stresses practices as "first and foremost performances... [since] practices only exist to the extent that they are reproduced." He further stresses that practice-oriented approaches "describe important features of the world we inhabit as something that is routinely made and re-made in practice, using tools, discourse and our bodies. From this perspective, the social world appears as a vast array or assemblage of performances made durable by being inscribed in skilled human bodies and minds, objects and texts and knotted together in such a way that the results of one performance become the resource for another. Practice-based approaches offer a new vista on all things social by foregrounding work, materiality, process and knowledgeability." (Nicolini 2017, 20) 
products of what their practitioners do and say in particular cultural situations. They can do so by noting that action in cultural life always involves creativity and "play." The bundle of doing and saying one learns never is blindly repeated. It always depends on efforts to act and speak in new situations, on actively adapting what one has learned to suit changing circumstances. This creative aspect of practice permits "play" which can mark it out as special by turning particular cultural behaviors into performance events. By exploring, intensifying or otherwise setting apart some practices for special attention or focus, play helps to frame them as noteworthy. The play inherent to practice in cultural life enables its performativity. Practice always has "the potential for enacting self-awareness, or the possible thematization of an event sequence," permitting "people... to single out any event-any stretch of activity or moment of experience - and to dramatize or frame it as something special or something out of the ordinary," forming "a [dynamic and changing] continuum of more or less special events." (Lewis 2013, 7) Performativity shows "the potential... for human events to be highlighted or set apart, which is primarily a process of intensified reflection." (Lewis 2013, 27). Play is key to these performative processes, since play is what helps produce both social routines in rule-based activities through taking on roles and also enables the ambiguous testing and affirming of socio-cultural limits through experimental action. As such, play and performativity are parallel processes in relation to practice. When marked more by rules, play seeks to highlight or intensify experiences of freedom from constraint or of positive flow, while when play rises spontaneously, it often stresses the arbitrary or even absurd limits of boundaries in action. These interconnected processes often occur at the limits of conscious awareness; as embodied practices, they are often largely preconscious or implicitly intended.

Since both play and performativity pattern human experience, both are key to human cultural life. Using a performative approach to cultural activity highlights special types of performance activity like theater, puppets, masks, and spirit possession since they are distinctive types of role-enacting and identitycreating events. These special types of activity often "involve an enactment of issues concerning both personal and group cultural identity" (Lewis 2013, 19). They work by permitting the "elaboration or intensification of role constructs that are widely recognized but remain fertile because the situations portrayed are often ambiguous or even paradoxical." (Lewis 2013, 19)

Artistic practices are thus special types of practice that have been analyzed using practice theories for more than three decades. Although central to work in the arts, practice is also diverse, consisting of many different activities needed to bring the artistic work to life, to distribute it, and to give it meaning. Besides practices tied to skills such as dance, creative writing, musical score/ 
performance, theatre/performance, visual exhibition, design, filmmaking, often in various combinations, artistic practice also needs the work of promotion, sponsorship, audience, assessment, and scholarship. Henk Borgdorff sees artistic practices as a subset of cultural practices which form a special sort of embodied knowledge articulated through creative processes and in the art object (Borgdorff 2012, 39). Through the "work of art" - meaning the situated activities of artists and the results of their work - artistic practices consist of the "objects, processes and contexts" of artists' activities. (Borgdorff 2007, 9) But since artistic practice is linked with the distribution and interpretation of works of art, these complex special practices can be researched for their "aesthetic, hermeneutic, performative, expressive and emotive points of view" (Borgdorff 2007, 10). The contexts of artistic processes and objects likewise remind us that artistic practices "are always situated and embedded," always "saturated with experiences, histories and beliefs." So researching the artistic practices requires admitting and addressing their "embeddedness and situatedness in history, in culture (society, economy, everyday life) as well as in the discourse on art." (Borgdorff 2012, 46) This broader scope of artistic practices gives them a key place in the workings of cultural ecosystems tied to art worlds. To understand these practices, it is useful to start by looking at what those involved in artistic practices - artists, audiences, critics, scholars -- as interested parties do and say.

Artistic practices are very diverse, so it is worthwhile seeing those constituting the performing arts falling on a spectrum or filling a space. For the spectrum, on the one side, performers (actors, dancers, musicians) traditionally struggle to master highly codified bodily skills which they "act out" or perform in live contexts; while one the other side, performers also learn to embody freedom and creativity in their performance. How performing artists learn and use these diverse skills in any given situation ranges across this spectrum, from the one end stressing the virtuosity of patterned artistic activities according with established norms and models to the other end, stressing improvisation and experimentation at work in more uncodified and unpredictable events. (Arlander 2011, 317) While actual performances by artists may be located at various points along this spectrum, those at both ends require different types of artists who "play" with the practices. Since performance fall along a range of expressions, practices, and activities, they permit one to ground bundles of practice within performance situations which can then be used to analyze the performing arts.

Practice theories can also help strengthen, redirect, and refine research on/ in/through performance practices. By stressing the centrality of action and performance, and examining human patterns of behavior in the work of the 
performing arts, practice theory positions practice as the first object of enquiry and consequently reveals embodied actions, meaning formed by doing, and the performance of everyday work. Currently performance studies lack wideranging and detailed empirical studies of professional practice in other fields, like schools, medicine, and other professional settings.

\section{Performance Cultures as Creative Ecologies}

Performance can be seen as an embodied, situated, and sharable set of practices. ${ }^{9}$ Diana Taylor begins her recent book Performance noting how performing artists have been "placing the body FRONT AND CENTER in artistic practice... [as] the living flesh and the breath of the act itself" (Taylor 2016, 1). Work done in performance projects centers on kinds of living aesthetic experiments grounded in bodies that play with ways to say and do things in specific spaces and with specific audiences. Besides being a type of practice, a performance is also "an embodied, live, and in-situ event." (Fuentes 2015, 86). A performance always implies a space and an audience, where the practice of "performance is a doing to, a thing done to and with the spectators" (Taylor 2016, 86). Seeing performance as embodied practices and events where practices are creatively put to work means these practices and events of performance are never fixed, always in play, since performers never just try to replicate what is there, what they know or are capable of. Moreover, since the space and the other things and people who are part of the performance always surprise, performers always play with what they know or what they can do. Performers need and normally want to do something new in the performance, to add something to what we didn't hear, see, experience or feel before, to present us with a new look or a new face. This grounds performance in a living culture. More comprehensively, Meiling Cheng sees "[p]erformance as an intentional construct emerging out of the creative ecology of five irreducible, interwoven and mutually affecting elements: 'the time-space-action-performer-audience matrix" of theatricality." (Cody and Cheng 2015, 10; Cheng 2002, 278). ${ }^{10}$ The space of the

$9 \quad$ Performance is produced from "the corporeal know-how of practice, as the organising ethos of practice, as the experienced import of practice." (Bierncki 1999, 7).

10 Cody and Cheng $(2015,11)$ specifies performance as "a floating affect occasioned by the interplay among the five constitutive elements in any performance artwork: 'the timespace-action-performer-audience matrix of theatricality." (see also Cheng 2002, 278). They view theatricality as separate from theatre. Rather than emerging from what is staged or performed, it emerges from what a viewer notices in what is staged or performed, whether in the performers, the stage scenes or objects, in the space or in their interaction. 
performance practices during an event is thus a live interaction between performer and audience can be interpreted as a creative matrix or a kind of cultural ecology.

How do we understand performance cultures in relation to the arts and humanities? Exploring practice theory and its relation to new developments in performance studies will help to play with how practice approaches and performance studies can suggest their relations to ecological analysis. This paper will consider the usefulness of ecological approaches to exploring performances for the three Bangkok groups considered here.

Those practicing theatre and performance use their bodily skills and knowledge to play, but what they do in their play is their work. The practical process of creating performances is long and complex and involves many interacting people, things, spaces and organizations besides the performers themselves. Long before artists begin their planning or their rehearsals, there are many involved in ensuring the performers can get going. When rehearsals begin, it often includes experimenting or playing games, imagining new scenarios, and other types of improvisation, while working to develop or enact a performance. These activities typically include trying things out to see how they look or sound, and what effects they might have. Playing around with words, movements, and interactions. The object of this focused playing around is to discover what seems to "work" for the production or project. Yet for these performers to refer to their rehearsals as play, even though that might be much closer to what they are really doing, seems to devalue their activities in a society where work is the only serious and valuable activity. It seems paradoxical to say that theatrical performers, visual artists, and athletes are workers who may be paid to play. This paradox makes the sorts of processes and events they create for others especially interesting for performance analysts.

As pointed out in the above example of the "face" and Marina Abromović's "The Artist is Present," performance cultures minimally consist of the copresence of a performer and a public or spectator in some kind of a shared space. Each involves distinct practices rooted in bodily interaction. This interactional quality of performance emerges in a living contact zone that includes people engaging ensembles of practices for both performing and viewing performances. Those involved in these contact zones form a cultural ecology of performance. The performance ecologies centered on these embodied, embedded and interactional forms of practice often depend on creative forms

Cheng (2002) sees "performance as an intentional construct arising from the interactive kinetics of the five structural units of the theatrical matrix - 'theatricality is both the quintessence and the culmination' of this matrix." 
of practice that frame or mark out as special ordinary practices and forms of expertise beyond any single artistic discipline used in theatre, dance, music or film. Directors, arrangers and choreographers, and performers regularly experiment and improvise with the practices they know best as they create new works, but normally base this on substantial interactive work. There is always a tension in the creative work between efforts to rehearse, refine and present what is familiar with experimenting and improvising with what is new.

Performance is thus central to cultural life. It is a complex, interdependent, fragile, but a resilient living thing. Performance in contemporary life is now often framed as a live performative mode - something embodied, ephemeral, mediated, and affective. It is less about figuring out what performances mean than about what performances do or how they work through their play with what is familiar. Performance often focuses now on how performance works as an ecology, in how it arranges and distributes living and non-living bodies in actual time and space to create sensations and experiences in the here and now. This gives live performance cultures a fragility like that of ecosystems.

Meiling Cheng's view of performance as a creative ecology provides both "a conceptual compass" and a creative template for noticing, navigating, interpreting and developing performances across multiple landscapes or spaces. Cody and Cheng later not only call this compass "the theatrical matrix" - which they abbreviate " $t \mathrm{tm}$ " - they also equate it with performance in the quasi-formula $p=t t m .{ }^{11}$ They do this to emphasize how this creative ecology can help to both engage and make performances, whether as special or as ordinary events. They see how it could be useful "to engage with myriad daily performative incidents" we face in daily life, those that may have become more habitual or routinized. ${ }^{12}$ The five elements form five entry points for self-reflexive onlookers to start making sense of, engaging or even making any performances. The goal of this more nuanced approach to performance is to enable one to move from along the spectrum from indifference to interest to involvement to immersion in performance.

From the above perspective, performance is always grounded in local practices, even though it depends on and seeks connections beyond the locale of its activity. Performance thus differs in different parts of the world. Focusing on contemporary theatres in Europe and North Americas, Andy Lavender

\footnotetext{
11 See Cody and Cheng $(2015,11)$.

12 While performance is usually seen as something emerging from work done on "the literal stage," Cody and Cheng $(2015,11)$ also note "it may also erupt from various performative acts happening on the stage of the body, the street, the open field, the gallery the petri dish, the screen, the canvas, and the sound - even from the shimmering surface of a meteorite or the interior of a mouth."
} 


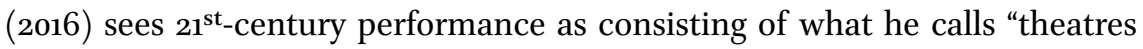
of engagement." For him, these theatrical activities mix performance up with a world more constituted by different modes of performance and performativity. Theatrical performance is now often mixed up in and difficult to separate from social processes, and current performance cultures tend to face outwards rather than inwards, even though many performances seem to include highly intimate or personal sharing or exposure. The common expectations of performance in our time also asks for the commitment, reaction, and sometimes sacrifice of those taking part in it, whether participants or spectators, with both often depending on and producing feelings and deep experiences.

For much of the $21^{\text {st }}$ century so far, many Asian theatre groups - including the three considered below based in Bangkok - have been on the move and mixing things up. They often work across national boundaries through intercultural performance exchanges and collaborations grounded in mobility and alliances. They tend to be involved in transnational, intercultural, collaborative, networked, hybrid performance-making processes and events. They form new connections and work across and between performance genres on itinerant platforms, forming mobile creative ecologies. While Europe and North America once provided much of the venues and support for this type of creative work, increasingly it is emerging from within the region.

\section{Performance Cultures Rooted Diverse Creative Ecologies}

Groups involved in performance are complex, interactive, interdependent, living assemblages of practices put in play to design, rehearse and perform works with and for others. These assemblages can be considered as special cultural ecosystems. Baz Kershaw suggested that "[ $t$ ]heatre ecology is the ways theatres behave as ecosystems" (Kershaw 2007, 16). Central to this theatre ecology approach is seeing how performances are attuned to the "mutual vulnerability" of performers and audiences (Kershaw 2007, 238).

Performance ecologies are firstly ecologies of practice, pointing to specific ways performance rises from a situated and interconnected set of practices enacted by particular groups rooted in specific sites that are grounded in communities as parts of local environments. The ecologies produce their own interdependent forms of life. They have their own networks and systems of support; and they are also always at risk of dying out. Despite their precarity, performance ecologies contribute to the wider ecosystem of performance, whether "classical" "traditional" "professional" or "community" - or to other forms of participatory performance. Viewing an ecology of performance practices 
underscores their place in the fluidity, fragility, interdependence, resilience of cultural life.

The small theatre groups based in Bangkok considered here form types of "poor theatre" - in Jerzy Grotowski's sense - which also could be seen as "minor theatres" - to repurpose Gilles Deleuze and Félix Guattari's analysis of Franz Kafka's "minor literature."13 But they also constitute significant niche cultural ecologies in Bangkok's theatre landscape. The practices forming their performance activities are a productive matrix which needs space for interactive work but since these spaces and their theatres are disappearing, they are looking for other grounds for their performance ecologies. They often develop performance work that is inclusive, modest, interrogative, humble, and indeterminate.

How are performance cultures part of creative ecologies? Kershaw (2007) saw the ecological contributions of performance as assuming the form of the theatrical medium itself. Like in the discussion of Cheng (2002), this ecological perspective stresses performance as a relational activity - emerging through the interactions between actors and audiences in particular spaces - which produces what Fischer-Lichte calls "autopoetic feedback loops" (Fischer-Lichte 2008 , 39). Performers and audiences are mutually exposed - physically present and mutually at risk - immersed in complex stagings of "nature," "technology" and "culture" embedded in "assemblages" or "networks," humans part of a larger ensembles of objects, technologies, and processes. In this environment, studying performance consists of work "to create diverse and dynamic research ecologies for the future." (Kershaw and Nicholson 2011, 3) The ecological time of theatre is made up, malleable and multi-scalar in ways that challenge the limited (and limiting) times of our uncertain modernity. Finally, performances and performers are part of a complex intra-active workings of larger interdependent wholes open to the wider world, where no one is in charge.

\section{A Preliminary Look at Three Performance Ecologies in $21^{\text {st }}$-Century} Bangkok Using a Practice and Performance Approach

The above framework will help to sketch out how theories of practice and performance could help to make sense of three key $21^{\text {st-century groups in }}$

\footnotetext{
13 Deleuze and Guattari (1986). "Minor" names a type of cultural production - replacing Kafka's literature for Deleuze and Guattari with the performance considered here - from inside a dominant culture. It shows a kind of "becoming a stranger" in one's own cultural home. "Minor" also points to the production of a collective acting or voicing which could produce audiences-yet-to-come who are, in some sense, already here.
} 
Bangkok's performance landscape discussed at the start of this paper. ${ }^{14}$ I suggest how this approach could show how the three groups developed distinctive bundles of performance practices that they use to produce diverse types of performance making as performance ecologies. This section provides some of guideposts for how this type of analysis could be done. While only small parts of the overall performance landscape of the city, these three groups have produced durable, significant, and distinctive performance ecologies which have involved and gotten transnational attention.

Performance groups in Bangkok have recently been challenged to find spaces for their work. In the last few years, several noteworthy small theatre spaces have closed. They had been key sites for rehearsals and performances for many small contemporary performance groups in the city. Besides the closing of the widely used Pridi Banomyong Institute on Thonglor, the Democrazy Theatre Studio near Lumpini Park and the Thonglor ArtSpace all shut their doors. ${ }^{15}$ Despite this challenge, the three groups discussed in this paper have been able agile and innovative enough to continue developing their artistic practice as itinerant performers working to design mobile creative ecologies.

Although the Pichet Klunchun Dance Company has been "closed" since 2017, its new Chang Theatre in Thonburi has still been home to many performances. The dance work of this group continues to base itself on giving traditional Thai classical dance a contemporary sensibility, while retaining the heart and wisdom of the tradition. Still performing some older works from its repertoire for audiences in Japan, Taiwan, Europe and other countries in these years, the company has also been working on new collaborative pilot projects with other artists in the region. The company has only presented some preliminary works-in-progress to the public in the last two years, all hinting at a new direction for its contemporary dance rooted in Thai tradition, and sometimes including the use of interactive action painting, and object-centered forms of movement. Still the premier home for independent dance in Thailand, the

14 It is based on recent interviews with members of the three groups in 2019 and 2020 and the long observation of their work.

15 The renovation of the Pridi Institute on Thonglor in 2017 left two theatre companies long house there -- Crescent Moon Theatre and B-Floor Theatre without their working and performance space. Closing in April 2019 was the Democrazy Theatre Studio, co-founded by Pavinee and Thanapol Virulhakul in 2008 as a black box theatre in two shophouses on Soi Saphan Khu, off Rama IV Road near Lumpini Park. It could hold an audience of 60 after staging about 70 often politically charged shows and contemporary performances there. The Thonglor ArtSpace opened in 2015 from a former guesthouse, likewise closed in 2019. 
company trains young professional dancers for contemporary movement, continues to experiment with diverse visuals and soundscapes, and new onstage creative interactions with objects, and letting its dancers develop their own individual works.

Nikorn Saetang's $8 \times 8$ Theatre Group has done numerous new and older works in the last two years, in Thailand, Japan, and elsewhere. Typically working with other performers on projects in many different spaces, these works mostly use Nikorn's original scripts (many published and translated), his talents in movement, physical theatre, mime, object theatre, and masks, and his directing acumen form the practical basis for developing performances. He has also established a strong reputation for creating complex aquascapes. He wrote and staged Marie Antoinette In A Musical with Lab 5 Soundworks in November 2018. In March 2019, he worked with Nuttapol "Ta" Kummata, part of the pantomime trio Babymime, on a family-oriented improvisational piece called Play Around Objects, which consisted of scenes where Nikorn and Ta played with household objects as they took audiences through a living room, office, outer space and under the sea. In June 2019 he improvised a scene on washing clothes by hand for the Thai exhibition "Same, Same But Different" at the Prague Quadrennial and also created and ran the live "Read-Listen-Go" play reading and happening (directed by performers without rehearsal). In March 2020, during the early COVID 19 outbreak, Nikorn went to Tokyo to work with Yoji Sakate on a reprise of Nikorn's play Where Should I Lay My Soul? about a restless spirit of the Yasukuni Shrine.

The B-Floor artist collective remains a diverse group of artists from various backgrounds who integrate physical theatre, object theatre, multimedia work, complex nonlinear performances and a space for workshops and performances, often taking on socio-political issues in nuances ways. The B-Floor theatre brand keeps lead members and co-artistic directors Jarunun and Teerawat busy, with currently include 8 or so others in the collective. Jarunun has also been the co-founder and dramaturg for publishing called "Collective Thai Scripts." One major international recent collaborative work of the group was the political and social drama of memory, passion, painting trauma and history, based on the $18^{\text {th }}$ novel by Uthis Haemamool, Silhouette Of Desire and called Pratthana - A Portrait of Possession, co-created Toshiki Okada and Jarunun, and choreography by Yuya Tsukahara, with a Thai cast and Japanese crew. After its September 2018 premier in Bangkok, it showed in Paris in December 2018 and was staged in Tokyo 2019, all with support from the Japan Foundation. In 2019 Teerawat developed with B-Floor a physical and object-oriented performance The (Un)Governed Body, which explored the body and mind in various 
states like trance, meditation, vulnerability and powerlessness, as seen in the current popularity of spiritual mediums in Thailand. It grew from the work-inprogress done in May, and was performed in Japan in August, and in Thailand and Indonesia in September. There was also a restaging of B-Floor's 2011 piece Damage Joy in October 2019 at the BACC in Bangkok, where four clowns escalate how they hurt one another and destroy things for their entertainment, with audiences given the opportunity to say whether they have gone too far.

By briefly exploring some aspects of the distinctive performance ecologies of the Pichet Klunchun Dance Company, Nikorn Saetang's 8X8 Theatre Company, and the B-floor artist collective which emerged in the wake of the 1997 Asian Financial Crisis, we see the importance of developing diverse sets of performing arts practices by people - artists, audiences, and sponsors - committed to the performing arts over time. All three of these groups have been recognized as key elements of the constellation of performance constituting the $21^{\text {st }}$ century performance landscape in Bangkok. Although often struggling to find spaces and funding to support their work, their dedication to their distinctive forms of performance over the last 20-plus years has helped to make them recognized with committed fans and funders for their work. Over the years, they have all received the Silpatorn award given by the Office of Contemporary Arts (OCA), Ministry of Culture of Thailand in recognition of their role as living Thai contemporary artists. They all have performed and held workshops widely in foreign countries, especially in the Asia-Pacific region. During the covid 19 outbreak in 2020, while many of their plans for their work were suspended, delayed or even cancelled. The Office of Contemporary Arts provided 10 Silpatorn artists and 42 other performing arts groups with some small funding in May 2020 to do performance projects which they would record or perform in some safe venue - whether live before an audience or just before a camera and submit it to the OCA Facebook page in June 2020 for others to view. Despite this work, each of the artists are still developing strategies, new practices, and viable work for their post-covid lockdown performances.

\section{9}

\section{Concluding Remarks}

This article has considered three performance groups in Bangkok as embedded in performance ecologies of a cultural environment that emerged in the wake of the Asian Financial Crisis of 1997. Within this environment, what distinguishes the performance ecologies of the Pichet Klunchun Dance Company from the B-floor artist collective and from Nikorn Saetang's $8 \times 8$ Theatre are 
distinct sets of embodied, situated, embedded performance practices that constitute their unique forms of artistic and creative work. Given the drastic changes forced on performing arts groups brought about in the current COVID 19 pandemic outbreak both here in Bangkok and around the world, all performance groups have had to radically modify their working practices and goals, including the three considered here.

With performance spaces shut since March 2020 during the Bangkok lockdown, some groups have continued to work on projects in anticipation of the re-opening of live performance venues later in the year, but many others have sought to develop new live or recorded digital venues through online platforms like Zoom, Facebook Live, or Skype. These immediate creative responses will likely require deeper changes for the performing arts going forward, given the severe long-lasting economic downturn that is expected for both companies and countries, requiring a major transformation in their performance ecologies, too. Still, the will to performance in Bangkok will not end groups seeking for ways to create the delights of live performance remotely, seeking practical and improvisational responses to create new connections among performers and with audiences, and to discover new ways to share performing together.

In the post-COVID 19 world, performance ecologies in Bangkok will likely see two trends. First, there will likely be more mediatization of performance, with further integration of virtual media into live performance. Second, the enhanced appreciation for the power of live, embodied, and shared performance will increase. Being forced to spend so much time apart from one another may help us to better appreciate the importance of being together with other people in creative spaces. Like groups in the post-Asian Financial Crisis period, finding performance spaces and funding will likely be more challenging. This will likely mean that beyond greater use of online forms of performance like Zoom, Skype, and Facebook Live, existing public spaces like universities, schools, museums, cultural centers, and even malls, will become more important as venues. There may also be some more repurposing of private spaces such as using homes or shops for rehearsals and performances, a phenomenon from the past but also currently occurring. Funding for performances will also likely depend more on universities and other schools, government support, private sponsorship, and foreign sources. The new era of "poor theater" will also likely lead to more diverse and experimental forms of applying performance techniques to diverse situations that occur offstage and out of the theater. Continued support for the new Research Cluster in Arts and Culture at Chulalongkorn University begun 2018 is one way that these trends can 
in promoting the performing arts be both encouraged and enhanced for the post-Covid theatre world.

In Bangkok after COVID-19, performance will still be necessary since it will likely be hyperlocally focused. But there will also be options to become more globally interconnected through these digital forms of sharing creative performances. In a best-case scenario, performance will entertain and serve the community, create more resources for those with little access, and move toward an equity that our current class-based industry can now only dream of.

\section{References}

Arlander, Annette. 2011. "Characteristics of Visual and Performing Arts." In Routledge Companion to the Arts, edited by Michael Biggs and Henrik Karlsson, 315-332. London: Routledge.

Bierncki, Richard. 1999. Beyond the Cultural Turn: New Directions in the Study of Society and Culture. Berkeley \& Los Angeles: University of California Press.

Borgdorff, Henk. 2007. "The Debate on Research in the Arts." Dutch Journal of Music Theory 12 (1): 1-17.

Borgdorff, Henk. 2012. The Conflict of the Faculties: Perspectives on Artistic Research and Academia. Leiden: University of Leiden Press.

Cheng, Meiling. 2002. In Other Los Angeleses: Multicentric Performance Art. Berkeley \& Los Angeles: University of California Press.

Cody, Gabrielle, and Meiling Cheng, eds. 2015. Reading Contemporary Performance: Theatricality across Genres. London: Routledge.

Daney, Serge. 2004 [1992]. "The Tracking Shot in Kapo," Senses of Cinema 30. Accessed June 10, 2019. http://sensesofcinema.com/2004/feature-articles/kapo_daney/.

Deleuze, Gilles, and Félix Guattari. 1986. Kafka: Toward a Theory of Minor Literature. Translated by Dana Polan. Minneapolis: University of Minnesota Press.

Diamond, Elin, ed. 1996. Performance and Cultural Politics. New York: Routledge.

Fischer-Lichte, Erika. 2008. The Transformative Power of Performance: A New Aesthetics. London \& New York: Routledge.

Fuentes, Marcela A. 2015. "Performance, Politics, and Protest." In What is Performance Studies?, edited by Diana Taylor and Marcos Steuernagel, Durham: Duke University Press; New York: HemiPress <https://scalar.usc.edu/nehvectors/wips/index>.

Hui, Allison, Theodore Schatzki, and Elizabeth Shove. eds. 2017. The Nexus of Practices: Connections, Constellations, Practitioners. New York: Routledge.

Kershaw, Baz. 2007. Theatre Ecology: Environments and Performance Events. Cambridge: Cambridge University Press. 
Kershaw, Baz, and Helen Nicholson. 2011. "Introduction: Doing Methods Creatively." In Research Methods in Theatre and Performance Studies, edited by Baz Kershaw and Helen Nicholson, 1-15. Edinburgh: Edinburgh University Press.

Lavender, Andy. 2016. Performance in the Twenty-First Century: Theatres of Engagement. London: Routledge.

Lewis, J. Lowell. 2013. The Anthropology of Cultural Performance. New York: Palgrave MacMillan.

Nicolini, Davide. 2017. "Practice theory as a package of theory, method and vocabulary: affordances and limitations." In Methodological Reflections on Practice Oriented Theories, edited by Michael Jonas, Beate Littig, and Angela Wroblewski, 19-34. Berlin: Springer International Publishing.

Postill, John. 2010. "Introduction: Theorising media and practice." In Theorising Media and Practice, edited by Birgit Bräuchler and John Postill, 1-22. Oxford and New York: Berghahn Books.

Reckwitz, A. 2002. "Towards a theory of social practices." European Journal of Social Theory 5 (2): 243-63.

Schatzki, Theodore R., Karin Knorr-Cetina, and Eike von Savigny, eds. 2001. The Practice Turn in Contemporary Theory. London: Routledge.

Schatzki, Theodore R. 2001a. "Introduction: Practice Theory." In The Practice Turn in Contemporary Theory, edited by Theodore R. Schatzki, Karin Knorr-Cetina, and Eike von Savigny, 1-14. London: Routledge.

Schatzki, Theodore R. 20o1b. "Practice Mind-ed Orders." In The Practice Turn in Contemporary Theory, edited by Theodore R. Schatzki, Karin Knorr-Cetina, and Eike von Savigny, 42-55. London: Routledge.

Shove, Elizabeth, Mika Pantzar, and Matt Watson. 2012. The Dynamics of Social Practice: Everyday Life and How it Changes. Boston: Sage.

Taylor, Diana. 2016. Performance. Durham: Duke University Press.

Warde, Alan. 2005. "Consumption and Theories of Practice," Journal of Consumer Culture 5(2): 131-153.

Welch, D., and Alan Warde. 2015. "Theories of Practice and Sustainable Consumption." In Handbook of Research on Sustainable Consumption, edited by Reisch, Lucia A, and John Thøgersen, 84-100. Cheltenham, UK: Edward Elgar Publishing. 